illegal production, acquisition, storage, transportation, shipment without the purpose of sale of drugs]. Yurydychnyi naukovyi elektronnyi zhurnal, 6, 337341. Retrieved from: http://www.Isej.org.ua/6_2019/82.pdf (in Ukrainian)

3. Hrianka, H. V. (2011). Administratyvna vidpovidalnist za pravoporushennia u sferi nezakonnoho vyrobnytstva, prydbannia, zberihannia, perevezennia, peresylannia narkotychnykh zasobiv abo psykhotropnykh rechovyn bez mety zbutu $v$ nevelykykh rozmirakh [Administrative liability for offenses in the field of illegal production, acquisition, storage, transportation, shipment of narcotic drugs or psychotropic substances without the purpose of sale in small amounts]. Borotba z orhanizovanoiu zlochynnistiu i koruptsiieiu (teoriia i praktyka), 24, 163-170 (in Ukrainian)

4. Shevchuk, H. V. (2013). Administratyvno-pravova protydiia militsiieiu nezakonnomu obihu narkotychnykh zasobiv, psykhotropnykh rechovyn ta prekursoriv [Administrative and legal counteraction by the police to illicit trafficking in narcotic drugs, psychotropic substances and precursors]. (Dissertation, Doctor of Law). National Aviation University, Kiev (in Ukrainian)

B. Kindyuk, Dr of Law, director of the laboratory

The Odessa State University of Internal Affairs, Odesa, Ukraine
5. Shevchuk, H. V. (2010). Nedoliky administratyvnykh pokaran u pravakh pro pravoporushennia v sferi obihu narkotychnykh zasobiv ta psykhotropnykh rechovyn [Disadvantages of administrative penalties in cases of drug and psychotropic substance trafficking]. Chasopys Kyivskoho unыversytetu prava, 4, 150-154 (in Ukrainian)

6. Havrylova, I. O. (2015). Osoblyvosti administratyvnoi vidpovidalnosti inozemtsiv ta osib bez hromadianstva [Features of administrative liability of foreigners and stateless persons]. Naukovyi visnyk Khersonskoho derzhavnoho universytetu. Seria: Yurydychni nauky. 5 (2), 99-102 (in Ukrainian)

Received: $15 / 09 / 2020$

1st Revision: $20 / 10 / 2020$

Accepted: $14 / 11 / 2020$

\title{
ADMINISTRANIVE LIABILITY OF FOREIGNERS AND STATELESS PERSONS FOR OFFENCES IN THE FIELD OF TURNOVER OF DRUGS, PSYCHOTROPIC SUBSTANCES AND PRECURSORS
}

The article deals with administrative procedure for offences committed by foreigners and stateless persons in the field of drug trafficking, as well as the features of administrative and preventive measures that are applied. The methodological basis of the study include a systematic approach, which considers a system of administrative measures aimed at combating drug trafficking; logical-semantic method, which is used to develop the conceptual apparatus; comparative legal method used for the analysis of the limit values of the size of drugs in different countries, etc. It is emphasized that for administrative offenses of this category such persons are brought to administrative liability on the grounds common to the citizens of Ukraine. Such persons can also be brought to administrative liability for offences involving the illicit trafficking of drugs in small sizes without the purpose of sale. Proceedings in cases of administrative offenses related to illicit trafficking of drugs and psychotropic substances can be understood as a special type of activity of authorized bodies, which is aimed at bringing to administrative liability those who have committed administrative offenses in this area. It is established that the procedure for introducing administrative offenses related to drug trafficking committed by foreigners and stateless persons follows the stages established by the administrative legislation of Ukraine. It is shown that this category of people should be informed on the maximum size of these hazardous substances, which differ significantly from similar indicators that are accepted in other countries. According to the current legislation, for administrative offenses related to drug trafficking, foreigners and stateless persons may be subject to administrative deportation, reduction of the period of temporary stay on the territory of Ukraine, forced return to the country from which they arrived.

Keywords: administrative legislation of Ukraine, administrative liability, administrative coercion, foreigners and stateless persons; drugs; limit sizes.

Bulletin of Taras Shevchenko National University of Kyiv.

Legal Studies, 2020; 3 (114): 25-30

удк: $347.157: 340.5$

DOI: https:doi.org/10.17721/1728-2195/2020/5.115-6
ISSN 1728-2195

C) Taras Shevchenko National University of Kyiv

Publishing center "Kyiv University", 2020

К. Кравченко, юрист I категорії, Б. Шлоер, д-р юрид. наук (нім.), доц.

Київський національний університет імені Тараса Шевченка, Київ, Україна

\section{НЕПОВНОЛІТНІ ЯК СУБ'ЄКТИ ПРАВА: ПОРІВНЯННЯ ПРАВОВОГО РЕГУЛЮВАННЯ В НІМЕЧЧИНІ Й УКРАЇНІ}

Досліджено питання, які стосуються неповнолітніх як суб'єктів права. Неповнолітні не мають достатнього інтелектуального розвитку для того, щоб розуміти наслідки своїх дій. Саме тому вони потребують особливого правового захисту. Це дослідження сфокусовано на окремих аспектах цивільного та сімейного права.

Проаналізовано законодавство Німеччини й України, що стосується неповнолітніх. Установлено, що ні в німецькому, ні в українському праві нема одностайності щодо визначення віку осіб, які йменуються неповнолітніми. Більше того, цей термін у різних законодавчих актах тлумачиться по-різному. До осіб, які не досягли повноліття, застосовують такі терміни: неповнолітній, дитина та ін. Аналіз міжнародно-правового законодавства також не змінює ситуацію щодо термінологічної чіткості у розмежуванні або ідентичності розглядуваних понять.

Досліджено та проведено порівняльно-правовий аналіз меж віку в цивільному праві Німеччини й України. Установлено, що вікова градація тісно пов'язана з категоріями право- та дієздатності, які врегульовані цивільним законодавством. Порівняльно-правовий аналіз регулювання дієздатності в Німеччині й Україні показує, що цивільне законодавство Німеччини відрізняється від цивільного законодавства України у питанні дієздатності. Зокрема це стосується визначення поняття, видів і змісту, а також вікових меж.

Проаналізовано та порівняно норми Сімейного кодексу України та Цивільного кодексу Німеччини, які стосуються прав неповнолітніх осіб. Запропоновано зміни до Сімейного кодексу України в контексті поваги прав неповнолітніх.

Ключові слова: неповнолітні, права неповнолітніх, правоздатність неповнолітніх, дієздатність неповнолітніх, межі віку в цивільному праві.

ВСТУП. У давні часи неповнолітня особа (дитина) була об'єктом patria potestas та з розвитком суспільства перетворилася з об'єкта права на суб'єкт права. У різних країнах цей процес відбувався по-різному. Метою цієї статі $€$ порівняльно-правовий аналіз неповнолітніх як суб'єктів права в Німеччині та Україні. Стаття сфокусована переважно на цивільному та сімейному праві.
Аналіз останніх досліджень і публікацій дозволяє зазначити таке. Окремі аспекти прав неповнолітніх досліджували як українські вчені (О.В.Дзера, Н. В. Ортинська, 3. В. Ромовська, О. А. Шульц та ін.), так і німецькі [13, 25 та ін.]. Проте це питання залишається недостатньо дослідженим, а також нині нема достатньої кількості 
порівняльно-правових досліджень із країнами Європи, тому проблема стала особливо актуальною, зважаючи на євроінтеграційну політику в Україні.

\section{ВИКЛАД ОСНОВНОГО МАТЕРІАЛУ}

Порівняльний аналіз поняття неповнолітні. Поперше, потрібно визначитися з терміном неповнолітній. Цей термін може розглядатися у декількох значеннях (табл. 1).

Таблиця 1. Неповнолітні в німецькому й українському законодавстві: порівняння

\begin{tabular}{|c|c|c|}
\hline & Німеччина & Україна \\
\hline Дієздатність & $\begin{array}{l}\text { Діти (від } 0 \text { до } 7 \text { років) - недієздатні (§ } 104 \text { BGB } \\
\text { (Цивільного кодексу Німеччини)) } \\
\text { Неповнолітні (від } 7 \text { до } 18 \text { років) - обмежено діє- } \\
\text { здатні (§ } 106 \text { BGB) }\end{array}$ & $\begin{array}{l}\text { Малолітні (від } 0 \text { до } 14 \text { років) - часткова цивільна } \\
\text { дієздатність (ст. } 31 \text { ЦК) } \\
\text { Неповнолітні (від } 14 \text { до } 18 \text { років) - неповна } \\
\text { цивільна дієздатність (ст. } 32 \text { ЦК) }\end{array}$ \\
\hline Деліктоздатність & $\begin{array}{l}\text { Діти (від } 0 \text { до } 7 \text { років) - неделіктоздатні (§ } 828 \text { ч. } 1 \\
\text { ВGB) } \\
\text { Неповнолітні (від } 7 \text { до } 10 \text { років) - не відповідають } \\
\text { за шкоду, яка спричинена у результаті аварії, } \\
\text { за винятком навмисного характеру шкоди } \\
\text { (§ } 106 \text { BGB) } \\
\text { Неповнолітні (від } 7 \text { до } 18 \text { років) - обмежено } \\
\text { дієздатні (§ } 106 \text { BGB) }\end{array}$ & $\begin{array}{l}\text { Малолітні (від } 0 \text { до } 14 \text { років) - неделіктоздатні } \\
\text { (ст. } 1178 \text { ЦК) } \\
\text { Неповнолітні (від } 14 \text { до } 18 \text { років) - деліктоздатні } \\
\text { (ст. } 1179 \text { ЦК) }\end{array}$ \\
\hline $\begin{array}{l}\text { Заповідальна } \\
\text { дієздатність }\end{array}$ & $\begin{array}{l}\text { Заповідальна дієздатність неповнолітнього - } \\
16 \text { років (§ } 2229 \text { ВGB) }\end{array}$ & $\begin{array}{l}\text { Особа з повною цивільною дієздатністю - тобто } \\
\text { з } 18 \text { років (ст. 1234). До } 18 \text { років надається } \\
\text { особам у випадку диспенсації й емансипації }\end{array}$ \\
\hline Трудове право & $\begin{array}{l}\text { Дитина від } 0 \text { до } 15 \text { років } \\
\text { Неповнолітні від } 15 \text { до } 18 \text { років (§ } 2 \text { Закону про } \\
\text { охорону праці неповнолітніх) }\end{array}$ & $\begin{array}{l}\text { Неповнолітні (із } 16 \text { до } 18 \text { років - дозволено } \\
\text { працевлаштування). Винятки: } 15 \text { років, } 14 \text { років } \\
\text { (ст. } 187-188 \text { КзПП) }\end{array}$ \\
\hline Кримінальне право & $\begin{array}{l}\text { Неповнолітні від } 14 \text { до } 18 \text { років (§ } 1 \text { ч. } 2 \text { (Закон про } \\
\text { правосуддя у справах неповнолітніх)) } \\
\text { До } 14 \text { років особа не несе кримінальну } \\
\text { відповідальність (§ } 19 \text { StGB Кримінального } \\
\text { кодексу Німеччини) }\end{array}$ & $\begin{array}{l}\text { Неповнолітні (від } 16 \text { до } 18 \text { років - настання } \\
\text { кримінальної відповідальності, виняток від } 14 \text { до } \\
16 \text { років для особливо тяжких злочинів (ст. } 22 \text { КК) } \\
\text { При цьому відповідно до КПК: неповнолітня } \\
\text { особа - малолітня особа, а також дитина у віці } \\
\text { від } 14 \text { до } 18 \text { років (ст. } 3 \text { п. } 12 \text { КПК) }\end{array}$ \\
\hline Адміністративне право & $\begin{array}{l}\text { Адміністративна деліктоздатність неповнолітніх - } \\
\text { з } 14 \text { років (§ } 12 \text { Закону Німеччини про адміністра- } \\
\text { тивні правопорушення (OWiG)) }\end{array}$ & $\begin{array}{l}\text { Адміністративна деліктоздатність - із } 16 \text { років } \\
\text { (ст. } 12 \text { Кодексу України про адміністративні } \\
\text { правопорушення) }\end{array}$ \\
\hline $\begin{array}{l}\text { Законодавство про } \\
\text { захист дітей і молоді }\end{array}$ & $\begin{array}{l}\text { §1 Закону Німеччини про захист молоді (JuSchG)) } \\
\text { Діти - це особи, які не досягли } 14 \text { років. } \\
\text { Неповнолітні - це особи від } 14 \text { до } 18 \text { років }\end{array}$ & $\begin{array}{l}\text { Закон України "Про охорону дитинства" (ст. 1) } \\
\text { Дитина - особа віком до } 18 \text { років. }\end{array}$ \\
\hline
\end{tabular}

Відповідно до німецької доктрини права неповнолітньою в загальному (широкому) розумінні є особа, яка не досягла повноліття, тобто 18 років [1, с. 55; 2, с. 462]. У вузькому розумінні неповнолітньою називають особу, яка досягла 7 років, але не досягла 18 років (§ 106 Цивільного кодексу Німеччини (Bürgerliches Gesetzbuch далі BGB)) [2, с. 462; 3, с. 126]. Поняття неповнолітні у розумінні Закону Німеччини про правосуддя у справах неповнолітніх (далі JGG) не $є$ ідентичним із поняттям неповнолітніх у розумінні Цивільного кодексу Німеччини [3, с. 127]. Відповідно до § 1 JGG неповнолітніми визнаються особи, які досягли 14 років, та не досягли 18 років [4]. Подібний підхід відображено в Законі Німеччини про захист молоді (JuSchG) [5], § 1 якого містить наступні визначення: діти - це особи, які не досягли 14 років, а неповнолітні - це особи від 14 до 18 років.

В українському праві неповнолітньою вважають особу від 14 до 18 років, а особа до 14 років є малолітньою (ст. 31, 32 Цивільного кодексу України (далі ЦК)). У галузі трудового права України неповнолітніми вважають осіб, які не досягли 18 років (ст. 187 КзПП), тоді як у Німеччині - осіб від 15 до 18 років (§ 2 Закону Німеччини про охорону праці неповнолітніх).

Кримінальний процесуальний кодекс України (далі КПК) містить таке визначення: неповнолітня особа - це малолітня особа, а також дитина у віці від 14 до 18 років (ст. 3 п. 12 КПК), де малолітня особа - це дитина до досягнення нею 14 років (ст. 3 п. 11 КПК) [6]. Тобто, на противагу ЦК, КПК визначає неповнолітньою особу до 18 років. У той же час Закон України "Про охорону дитинства" (ст. 1) застосовує лише термін дитина та визначає його, як особу віком до 18 років [7].

Таким чином, як видно з табл. 1, ні в німецькому, ні в українському праві нема одностайності щодо визна- чення віку осіб, які йменуються неповнолітніми, та цей термін у різних законодавчих актах тлумачиться порізному. Більше того, аналіз законодавчих актів обох країн показує, що до осіб, які не досягли повноліття, застосовують терміни неповнолітній, дитина тощо. Як правило, частіше застосовують терміни неповнолітній або дитина, причому іноді терміни неповнолітній і дитина розуміють як ідентичні, тобто синоніми, а іноді під зазначеними термінами розуміють різні категорії осіб.

Українськими вченими це питання мало досліджувалося і не нема єдиної думки із цього приводу. Зокрема, серед українських учених існує думка, що дитина $€$ змістовно ширшим поняттям [8, с. 94] із ширшою віковою категорією $[9$, с. 58], ніж неповнолітній. Так, Н. В. Ортинська вважає, що до осіб від народження до досягнення 18 років необхідно застосовувати загальний термін "діти", а до осіб від 14 до 18 років - термін "неповнолітні" [9, с. 59]. Не можемо цілком погодитися із зазначеною думкою, особливо 3 твердженням щодо необхідності зазначення ознаки нижньої межі терміну дитина - "від народження".

Доцільним видається звернення до норм міжнародно-правового законодавства. Так, Конвенція про права дитини містить у ст. 1 таке визначення:

"Дитиною $є$ кожна людська істота до досягнення 18-річного віку, якщо за законом, застосовуваним до цієї особи, вона не досягає повноліття раніше" [10].

Визначення поняття неповнолітній у Конвенції відсутнє.

Визначення понять дитина або неповнолітній також відсутнє в Європейській Конвенції з прав людини (далі ЄКПЛ). До того ж ЄКПЛ не містить вікових обмежень $[11 ; 12$, с . 60, 129], що підтверджується формулюванням "усі особи" або "кожний". Тут потрібно звернути 
увагу на те, що в тексті Конвенції французькою мовою (toute personne), так само як і німецькою (alle Personen), іспанською (toda persona), італійською (ogni persona) зазначено "усі особи", а в тексті англійською (everyone), російською (каждый) та українською мовою зазначено "кожний".

Інші акти міжнародно-правового законодавства також не змінюють ситуацію щодо термінологічної чіткості у розмежуванні або ідентичності розглядуваних понять.

Для спрощення у межах цієї статті термін неповнолітній застосовуватимемо подібно до загального розуміння в доктрині німецького права, а саме, неповнолітній - це особа, яка не досягла повноліття, тобто 18 років.

Для неповнолітньої особи визначальним $€$ момент досягнення повноліття. В Україні, так само як і в Нiмеччині (§ 2 BGB), повноліття наступає з досягненням 18 років.

Межі віку в цивільному праві. Цивільний кодекс Німеччини базується на принципі приватної автономії 3 думкою про особисту відповідальність. Однак, цей ліберальний принцип потребує обмеження тоді, коли особи через свій вік ще не мають необхідного розуміння та вміння діяти самостійно у правових відносинах. Так, неповнолітні ще не мають достатнього рівня інтелектуального розвитку для того, щоб передбачити правові наслідки своїх дій. Тому законодавець прямо захищає цю категорію осіб [13, с. 97]. Закон має враховувати духовний і вольовий розвиток людини. Німецькі цивілісти зазначають, що правові гарантії не дозволяють приймати рішення, базуючись на розгляді окремої справи, але, наскільки це можливо, ґрунтуватися на фактах, що ідентифрікуються ззовні [14, с. 88]. Для цього існують ступені віку. Цивільний кодекс Німеччини розрізняє в цьому контексті три ступені віку: дитина до 7 років; неповнолітній із 7 до 18 років та особа після 18 років [14, с. 88]. Потрібно зазначити, що раніше, відповідно до § 2 BGB, віком настання повноліття вважався 21 рік. 1974 р., зважаючи на акселерацію та прискорений фрізичний розвиток неповнолітніх і зміни соціальних та економічних відносин, вік настання повноліття зменшено до 18 років [3, с. 10]. Правове значення такого розподілення полягає в тому, що дитина та неповнолітній пербувають під батьківським піклуванням (§ 1626 BGB) або отримують опікуна (§ 1773 BGB).

Вікова градація тісно пов'язана з категоріями право- та дієздатності, які врегульовані цивільним законодавством. Причому ці норми стосуються не лише всієї галузі цивільного права, а також часто і публічного права [3, с. 15].

Дієздатність - це здатність особи самостійно здійснювати дійсні правочини. Від дієздатності відрізняється правоздатність, тобто здатність особи бути носієм прав та обов'язків (§ 1 ВGB). Кожна людина є правоздатною, але може бути недієздатною або обмеженою у дієздатності [3, с. 15]. Відповідно до Німецького цивільного кодексу діти, які не досягли 7 років, $є$ недієздатними (§ 104 । BGB) [15]. Волевиявлення недієздатної особи $€$ недійсним (§ 105 I BGB). Вона також не може самостійно прийняти волевиявлення інших осіб щодо себе (§ 131 I BGB). Немає різниці, приносить волевиявлення дитині лише правові привілеї або ні, та чи зроблено воно за згодою законного представника [1, с. 55].

У німецькому праві проміжним ступенем між недієздатними та повністю дієздатними є обмежено дієздатні особи [3, с. 126]. Обмежено дієздатними є неповнолітні особи від 7 до 18 років. Обмежено дієздатна неповнолітня особа, як правило, здатна робити волевиявлення, дійсність яких залежить від згоди (попередньої згоди або наступного схвалення) їі законного представника (§ 107-113 BGB). Тобто неповнолітній здатен вчиняти правочини, але перебуває під контролем його законного представника (батьків, піклувальників). Отже, закон передбачає, що неповнолітній, хоч і здатний на юридично відповідно волю, не має достатнього рівня інтелектуальної зрілості чи досвіду, необхідного для безпечної участі у правових відносинах.

Однак законодавче регулювання не лише захищає цю групу осіб, але й дає їм змогу підготуватися до правового й економічного життя шляхом надання їм часткової дієздатності [3, с. 126]. Для обмежено дієздатних осіб передбачено більш диференційоване законодавче регулювання режиму захисту. Для них закон передбачає принаймні обмежену участь у правових відносинах $[13$, с. 98]. Захисна мета законодавчого регулювання полягає в тому, що неповнолітній може діяти самостійно тільки щодо правочинів, які приносять йому лише правову вигоду [3, сс. 127].

Автори коментарю до Цивільного кодексу Німеччини розрізняють волевиявлення неповнолітнього, яке приносить йому лише правові переваги, та інші волевиявлення. Волевиявлення, які приносять лише правову вигоду, є дійсними без участі законного представника (§ 107 BGB); стосовно інших волевиявлень, то значення має чи йдеться про договір або про одностороннє волевиявлення [16].

Окремої уваги заслуговує так званий "Taschengeld paragraf" (параграф про кишенькові гроші). Відповідно до цього параграфа, укладений неповнолітнім договір без згоди законного представника вважається дійсним, якщо він виконаний за рахунок коштів, які надані неповнолітньому для конкретної мети або у вільне розпорядження (§ 110 BGB). У доктрині німецького права пропонується звернути увагу на причину, з якої § 110 BGB встановлює сферу застосування згоди. Оскільки йдеться про виховні заходи - обмежено дієздатна особа має вчитися розпоряджатися фрінансовими засобами - відповідна воля законного представника $є$ пріоритетним аспектом над добросовісністю договірного партнера [13, с. 99]. У контексті Taschengeldparagraph слід звернути увагу на Загальний регламент про захист даних $€ C$ [17] (далі Регламент). Відповідно до ст. 8 Регламенту неповнолітні із 16 років можуть самостійно укладати договори 3 інтернет-провайдером, якщо йдеться про послугу інформаційного суспільства. Поняття послуги міститься у п. 26 ст. 4 Регламенту.

Часткова дієздатність існує також для певних юридичних правочинів, які пов'язані з бізнесом, що ведеться з дозволу законного представника (§ 112 BGB) або 3 договором про надання послуг або трудовим договором (§ 113 BGB), укладеним за його згодою. Для таких правочинів обмежено дієздатний неповнолітній є повністю дієздатним [3, с. 127]. Зазначимо, що $\S 112,113$ BGB можуть вважатися попередньою згодою на певну сферу життя. У зв'язку із цим неповнолітній частково здатний діяти (частково дієздатний), так що встановлену законом представницьку владу батьків у цій галузі призупинено [13, с. 98].

Цивільне право України відрізняється від німецького в питанні дієздатності. Відповідно до ст. 31 Цивільного кодексу України (далі ЦК) фрізична особа, яка не досягла 14 років (малолітня особа), має часткову цивільну дієздатність ${ }^{1}$, що надає їй право самостійно вчиняти дрібні побутові правочини та здійснювати особисті немайнові права на результати інтелектуальної, творчої діяльності, що охороняються законом. У цивілістичній доктрині висловлюються думки щодо встановлення необхідності досягнення малолітнім певного віку для вчинення вказаних вище дій, а також на розширення

1 Не плутати з наданням часткової дієздатності обмежено дієздатним особам у німецькому праві. 
переліку можливостей, які включаються до часткової дієздатності малолітньої фрізичної особи [18, с. 76].

Особа у віці від 14 до 18 років іменується неповнолітньою та має неповну цивільну дієздатність (ст. 32 ЦК). Обсяг дієздатності неповнолітньої особи значно розширений порівняно із частковою дієздатністю малолітньої особи. Особливістю українського цивільного права порівняно з німецьким цивільним правом $є$ також і те, що неповнолітня особа може набути повної цивільної дієздатності у випадку реєстрації шлюбу (ст. 34 ч. 2 ЦК), а також бути емансипованою на підставах, передбачених ст. 35 ЦК України. У Німеччині неповнолітня особа не має права укладати шлюб, оскільки вважається, що вона ще не володіє достатнім рівнем розумового та духовного розвитку, щоб приймати такі рішення та передбачати їх наслідки; до того ж ранні шлюби впливають на добробут і шанси на розвиток неповнолітньої особи [19]. А якщо неповнолітня особа з дозволу законного представника займається підприємницькою діяльністю, або вступає у службові або трудові відносини, то їй надається повна дієздатність лише для вчинення тільки тих правочинів, які необхідні для здійснення зазначеної діяльності. Щодо всіх інших правочинів неповнолітня особа залишається обмежено дієздатною до повноліття.

Деліктоздатність. Суттєва різниця між німецьким та українським правом спостерігається і у випадках, що стосуються регулювання деліктоздатності. Відповідно до німецького права діти, які не досягли 7 років $\epsilon$ неделіктоздатними (§ 828 । BGB). Особи у віці від 7 до 10 років $є$ неделіктоздатними у випадках аварій із моторними транспортними засобами або на залізниці, якщо тільки вони не діяли з наміром, наприклад, кидали каміння з мосту автобана на автомобілі, що проїжджають [20, с. 8]. Причиною такого положення $€$ те, що наукові дослідження показали, що діти до 10 років не можуть правильно визначити дистанцію та швидкість моторних транспортних засобів у дорожніх ситуаціях. Потрібно зазначити, що ці правила застосовують лише у випадках аварії з транспортними засобами або на залізниці [20, с. 8].

Неповнолітня особа, яка не досягла 18 років, у випадку, якщо її відповідальність не виключена § 828 II BGB, не відповідає за шкоду, якщо при заподіянні шкоди у неї було відсутнє розуміння, необхідне для усвідомлення своєї відповідальності (§ 828 III BGB).

У контексті деліктної відповідальності неповнолітнього потрібно зазначити, що в німецькій юридичній літературі [21, Rn. 875] та судовій практиці [22] висловлювалося, хоч і меншістю, конституційне занепокоєння щодо тягаря неповнолітнього заподіювача шкоди у вигляді загрози наявності обов'язку відшкодувати шкоду (у разі підтвердження відповідальності згідно з § 828 III BGB). Зокрема зазначається, що принаймні, якщо потерпілий не може обійтися без відшкодування, слід прокладати "зворотну аналогію" до § 829 BGB або вимагати конституційно необхідного виправлення § 828 III BGB на § 242 BGB, зменшення обсягу позову за умови, що цього вимагають індивідуальні обставини та справедливість. Нарешті, вкажемо, що § 828 BGB впливає також на заперечення, внесене згідно з § 254 BGB [13, с. 104].

Окремі аспекти сімейного права. Цікавим видається положення § 1626 ч. 2 BGB "батьківське піклування", відповідно до якого "батьки враховують зростаючу здатність і зростаючу потребу дитини до самостійних дій з усвідомленням своєї відповідальності". Вони обговорюють із дитиною, наскільки це доцільно, зважаючи на рівень їі розвитку, питання, які стосуються батьківського піклування та прагнуть взаємної згоди. Вказані положення не тільки відображають принципи німецького права щодо поваги прав дитини, урахування її думки, але й урахування зростаючої здатності усвідомлювати значення своїх дій. Починаючи з розвитку в сім'ї, через зростаючу можливість вступати в правові відносини, особа поступово набуває можливості проявляти себе й у галузі публічного права, чи то у сенсі релігійної зрілості, чи права голосу. Вважаємо, що це положення $€$ досить важливим і показовим у системі німецького права. У той час, як українське законодавство, хоч і слідуючи міжнародним нормам щодо захисту дітей, передбачає в п. 1 ст. 150 Сімейного кодексу України (далі СК) [23], що "батьки зобов'язані виховувати дитину в дусі поваги до прав і свобод інших людей", і в п. 5. ст. 150 СК, що "батьки зобов'язані поважати дитину", далі зазначаючи в ст. 155 СК, що "здійснення батьками своїх прав і виконання обов'язків мають ґрунтуватися на повазі до прав дитини та її людської гідності" та в ст. 171 СК, що "дитина має право на те, щоб бути вислуханою", що в суспільстві більше сприймається як можливість бути вислуханою "під час судового чи адміністративного розгляду" [23, с. 348], не приділяє уваги врахуванню зростаючої можливості усвідомлювати значення своїх дій і необхідності розмовляти з дитиною. На цьому прикладі можна простежити велику різницю у підходах німецького й українського законодавців та суспільства в цілому до поваги прав дитини як особистості.

Пропонуємо доповнити ст. 155 СК пунктом $1^{1}$ такого змісту:

"батьки мають враховувати зростаючу здатність і потребу дитини до самостійних дій з усвідомленням своєї відповідальності, зважати на рівень її розвитку й обговорювати з дитиною питання, що стосуються ії̈ виховання".

Водночас держава та батьки в першу чергу повинні піклуватися про добробут дитини у будь-якому контексті. Значущість порушеного правового блага та можлива незворотність втручання чи принаймні його наслідків породжують особливу вимогу захисту неповнолітнього. Таким чином, особливий обов'язок захисту держави та батьків співвідноситься не лише з приводу самостійності, але і з фізичною недоторканістю неповнолітньої особи [25, с. 785] або порушенням будьякого її інтересу або права.

Це обмеження, тобто встановлення здатності користуватися основними правами та ії̈ зіставлення з батьківським правом на виховання, у першу чергу справа законодавця. Німецький законодавець урегульовує всі сфери взаємовідносин з огляду на свободу договору, а також, враховуючи ризики ділового обороту (§ 112 BGB), тобто він має зважати на дієздатність фрізичної особи (§ 104 BGB) [26].

ВИСНОВКИ. Порівняння правового регулювання неповнолітніх в Німеччині й України дозволяє дійти таких висновків.

По-перше, установлено, що ні в німецькому, ні в українському праві нема одностайності щодо визначення віку осіб, які йменуються неповнолітніми, та цей термін у різних законодавчих актах тлумачать порізному, до того ж застосовують різні терміни для позначення однієї і тієї самої категорії осіб.

По-друге, порівняльно-правовий аналіз дозволяє дійти висновку, що існують відмінності між німецьким та українським правом щодо питання дієздатності, а саме, у визначенні поняття, видів, змісту та вікових обмежень. Відповідно до Німецького цивільного кодексу, діти, які не досягли 7 років $є$ недієздатними, а неповнолітні особи від 7 до 18 років - обмежено дієздатними. ЦК України передбачає, що фрізичні особи, які не досягли 14 років іменуються малолітніми та мають часткову дієздатність, а особи у віці від 14 до 18 років іменується неповнолітніми та мають неповну цивільну дієздатність. 
По-третє, зважаючи на акселерацію, прискорений розвиток неповнолітніх і зміни в суспільстві, вважаємо за необхідне дослідити чи було б правильно знизити вікову межу надання неповної дієздатності неповнолітнім особам в українському праві 314 до 12 років. ЦК України був прийнятий 16 років тому. За цей час темп життя змінився, важко порівняти 14-річну особу на початку 2000-х та в 2020 р. Сьогодні неповнолітні $€$ прогресивнішими особами, раніше стають дорослими та здатні приймати рішення, а також відповідати за свої дії.

По-четверте, гарантії захисту та повага до прав неповнолітньої особи досить міцно вкоренилися в Німеччині, з погляду правового регулювання і соціальносуспільних відносин. Дитина $€$ захищеною з правової точки зору, її права поважають навіть у сімейних відносинах, їй їх роз'яснюють. В Україні права дитини не мають такого ґрунтовного захисту як із погляду законодавчого закріплення, так і ментально-суспільного. Хоча фрагментарні норми щодо захисту неповнолітньої особи існують в українському законодавстві, але вони не завжди послідовні і кореспондуючі. Вважаємо, що необхідно переглядати норми щодо захисту неповнолітньої особи, з метою їхнього впорядкування й ефективнішого практичного застосування. Пропонуємо доповнити ст. 155 СК пунктом $1^{1}$ такого змісту:

"батьки повинні враховувати зростаючу здатність і потребу дитини до самостійних дій з усвідомленням своєї відповідальності, зважати на рівень її розвитку й обговорювати $з$ дитиною питання, що стосуються її виховання".

Список використаних джерел

1. Schwab D. Einführung in das Zivilrecht / D. Schwab // M. Löhnig. 20. Aufl. - C. F. Müller, Heidelberg, 2016.

2. Leenen D. BGB Allgemeiner Teil: Rechtsgeschäftslehre / D. Leenen. - 2. Aufl. - De Gruyter, Berlin, 2015.

3. Johansen K. H. Das Bürgerliche Gesetzbuch: mit besonderer Berücksichtigung der Rechtsprechung des Reichgerichts und des Bundesgerichtshofes. Kommentar / K. H. Johansen. - 12. Aufl., Band I. Walter de Gruyter, Berlin, 1982

4. Jugendgerichtsgesetz (JGG) vom 04.08.1953, in der Fassung der Bekanntmachung vom 11. Dezember 1974, BGBI. I S. 3427, zuletzt geändert durch Artikel 7 des Gesetzes vom 19. Juni 2019 BGBI. I. - S. 840.

5. Jugendschutzgesetz (JuSchG) vom 23. Juli 2002, BGBI. I S. 2730, zuletzt geändert durch Artikel 11 des Gesetzes vom 10. März 2017, BGBI. I. - S. 420 .

6. Кримінальний процесуальний кодекс України № 4651-VI від 13 квітня 2012 року // Відомості Верховної Ради України. - 2013. - № 9-10, № 11-12, № 13. - Ст. 88 (з останніми змінами від 21.07.2020)

7. Про охорону дитинства: Закон України від 26 квітня 2001 р. № 2402-III // Відомості Верховної Ради України - 2001 - № 30. - Ст. 142

8. Шульц О. А. "Права дитини" як категорія сучасного конституційного права / О. А. Шульц // Часопис Київського ун-ту права. - 2009. C. 91-96. URL: http://dspace.nbuv.gov.ua/bitstream/handle/123456789/ 22651/18-Shults.pdf?sequence=1 (дата звернення 10.04.2020)

9. Ортинська Н. В. Правовий статус неповнолітніх: теоретикоправове дослідження : дис. ... д-ра юрид наук: 12.00.01 / Н. В. Ортинська. - Львів, 2017. - 524 с.

10. Конвенція ООН про права дитини від 20 листопада 1989 року. URL: https://zakon.rada.gov.ua/laws/show/995_021\#Text (дата звернення 20.04.2020).

11. Marckx V. Judgement of ECHR / V. Marckx // Retrieved from Belgium, 13 June 1979, $\S 53$ et seq., Series A no. 31 . URL: http://hudoc.echr.coe.int/fre?i=001-57534 on 20.04.2020.

12. Grabenwarter Chr. Europäische Menschenrechtskonvention, 6. Aufl. / Chr. Grabenwarter, K. Pabel. - MANZ Verlag Wien, Helbing \& Lichtenhahn, C. H. Beck München, Basel, Wien 2016. - 688 S.

13. Staudinger A. Minderjährige im Zivilrecht / A. Staudinger, B. Steinrötter. - JuS 2012. - S. 97-105.

14. Hübner H. Allgemeiner Teil des Bürgerlichen Gesetzbuches / H. Hübner. - 2. Aufl. - Walter de Gruyter : Berlin; New York, 1996.

15. Bürgerliches Gesetzbuch (BGB) vom 18.08.1896. Neugefasst durch Bek. v. 2.1.2002 I 42, 2909; 2003. - 738, zuletzt geändert durch Art.7 G v. 12.7 .2018 I 54 .

16. Münchener Kommentar zum Bürgerlichen Gesetzbuch: BGB. - 8 . Aufl. - Verlag C. H. Beck, München 2018, § 106. - Rn. 13.

17. Регламент Європейського Парламенту і Ради (ЄC) 2016/679 від 27.04.2016 про захист фізичних осіб у зв'язку з опрацюваннями персональних даних і про вільний рух таких даних та про скасування Директиви 95/46 ЄС (Загальний регламент про захист даних) // Офіційний вісник Європейського Союзу 4.5.2016, 119/1. URL: https://www.kmu.gov.ua/storage/app/media/uploaded-files/es-2016679.pdf. (дата звернення: 16.07.2020).

18. Науково-практичний коментар Цивільного кодексу України. У 2 т. Т. 1 / за ред. О. В. Дзери, Н. С. Кузнєцової, В. В. Луця. - К. : Юрінком Інтер, 2005.

19. Sammet S. Graf Wolffskeel v. Reichenberg L. / S. Sammet // Wechselbezügliche Verfügungen Minderiähriger und das Gesetz zur Bekämpfung von Kinderehen, ZEV 2019. - 511

20. Magnus U. The Reform of German Tort Law / U. Magnus // InDret Working Paper Barcelona 2003, No. 127, Barcelona. Retrieved from URL: https://www.raco.cat/index.php/InDret/article/view/82541 on 25.08.2019.

21. Looschelders D. Schuldrecht AT / D. Looschelders. - 9. Aufl. Verlag Franz Vahlen, München, 2011.

22. Bundesverfassungsgericht. - BVerfG, NJW, 1998-3557.

23. Сімейний кодекс України від 10.02.2002 № 2947-ІІІ. Відомості Верховної Ради України. - 2002. - № 21-22. - Ст. 135 (з останніми змінами від 30.03.2020).

24. Ромовська 3. В. Сімейний кодекс України. Науково-практичний коментар / 3. В. Ромовська. К. : Iн Юре, 2003. - 532 с.

25. Lorenz A. Das Selbstbestimmungsrecht des einsichtsfähigen Minderjährigen bei Eingriffen in die körperliche Integrität / A. Lorenz. - NZFam 2017. - S. 782-788.

26. Stern K. Das Staatsrecht der Bundesrepublik Deutschland / K. Stern. Verlag C. H. Beck 1988, Bd. III/1, § 70. - V 2d.

\section{References}

1. Schwab, D., Löhnig, M., Einführung in das Zivilrecht, 20. Aufl., C.F. Müller, Heidelberg 2016 (in German)

2. Leenen, D., BGB Allgemeiner Teil: Rechtsgeschäftslehre, 2. Aufl., De Gruyter, Berlin 2015 (in German)

3. Johansen, K. H., Das Bürgerliche Gesetzbuch: mit besonderer Berücksichtigung der Rechtsprechung des Reichgerichts und des Bundesgerichtshofes. Kommentar, 12. Aufl., Band I. Walter de Gruyter, Berlin 1982 (in German)

4. Jugendgerichtsgesetz (JGG) vom 04.08.1953, in der Fassung der Bekanntmachung vom 11. Dezember 1974, BGBI. I S. 3427, zuletzt geändert durch Artikel 7 des Gesetzes vom 19. Juni 2019 BGBI. I S. 840 (in German)

5. Jugendschutzgesetz (JuSchG) vom 23. Juli 2002, BGBI. I S. 2730, zuletzt geändert durch Artikel 11 des Gesetzes vom 10. März 2017, BGBI. I S. 420 (in German)

6. Kriminalnij procesualnij kodeks Ukrayini № 4651-VI vid 13 kvitnya 2012 roku. Vidomosti Verhovnoyi Radi Ukrayini. 2013. № 9-10. № 11-12. № 13. St.88. (iz ostannimi zminami vid 21.07.2020) (in Ukrainian)

7. Pro ohoronu ditinstva: Zakon Ukrayini vid 26 kvitnya 2001 r. № 2402-III. Vidomosti Verhovnoyi Radi Ukrayini. 2001. № 30. St. 142 (in Ukrainian)

8. Shulc O. A. "Prava ditini" yak kategoriya suchasnogo konstitucijnogo prava ["Children's rights" as a category of modern constitutional law]. Chasopis Kiyivskogo universitetu prava. 2009. S.91-96. URL: http://dspace.nbuv.gov.ua/bitstream/handle/123456789/22651/18-

Shults.pdf?sequence $=1$ (data zvernennya 10.04.2020) (in Ukrainian)

9. Ortinska N.V. Pravovij status nepovnolitnih: teoretiko-pravove doslidzhennya [Legal status of minors: theoretical and legal research]: dis. d-ra yurid. nauk: 12.00.01. Lviv, 2017. $524 \mathrm{~s}$ (in Ukrainian)

10. Konvenciya OON pro prava ditini vid 20 listopada 1989 roku URL: https://zakon.rada.gov.ua/laws/show/995_021\#Text (data zvernennya 20.04.2020) (in Ukrainian)

11. Marckx v. Belgium, 13 June 1979, $\S 53$ et seq., Series A no. 31. Judgement of ECHR. Retrieved from URL: http://hudoc.echr.coe.int/ fre? $\mathrm{i}=001-57534$ on 20.04.2020 (in English)

12. Grabenwarter, Chr., Pabel, K., Europäische Menschenrechtskonvention, 6. Aufl., MANZ Verlag Wien, Helbing \& Lichtenhahn, C.H.Beck München, Basel, Wien 2016, 688 S (in German)

13. Staudinger, A., Steinrötter, B., Minderjährige im Zivilrecht, JuS 2012, S. 97-105 (in German)

14. Hübner, H., Allgemeiner Teil des Bürgerlichen Gesetzbuches, 2. Aufl., Walter de Gruyter, Berlin New York 1996 (in German)

15. Bürgerliches Gesetzbuch (BGB) vom 18.08.1896. Neugefasst durch Bek. v. 2.1.2002 I 42, 2909; 2003, 738, zuletzt geändert durch Art.7 G v. 12.7 .2018 I 54 (in German)

16. Münchener Kommentar zum Bürgerlichen Gesetzbuch: BGB, 8. Aufl., Verlag C. H. Beck, München 2018, § 106 Rn. 13 (in German)

17. Reglament Yevropejskogo Parlamentu i Radi (YeS) 2016/679 vid 27.04.2016 pro zahist fizichnih osib u zv'yazku z opracyuvannyami personalnih danih i pro vilnij ruh takih danih, ta pro skasuvannya Direktivi 95/46 YeS (Zagalnij reglament pro zahist danih), Oficijnij visnik Yevropejskogo Soyuzu 4.5.2016, 119/1. URL: https://www.kmu.gov.ua/storage/app/media/ uploaded-files/es-2016679.pdf. (data zvernennya: 16.07.2020) (in Ukrainian)

18. Naukovo-praktichnij komentar Civilnogo kodeksu Ukrayini [Scientific and practical commentary on the Civil Code of Ukraine]: u 2 t. / Za red. Dzeri O.V., Kuznyecovoyi N.S., Lucya V. V. Kiyiv: Yurinkom Inter, 2005. T.1 (in Ukrainian)

19. Sammet, S., Graf Wolffskeel v. Reichenberg, L., Wechselbezügliche Verfügungen Minderjähriger und das Gesetz zur Bekämpfung von Kinderehen, ZEV 2019, 511 (in Ukrainian)

20. Magnus, U. The Reform of German Tort Law. in: InDret Working Paper Barcelona 2003, No. 127, Barcelona. Retrieved from URL: https://www.raco.cat/index.php/InDret/article/view/82541 on 25.08.2019 (in English) 
21. Looschelders, D., Schuldrecht AT, 9. Aufl., Verlag Franz Vahlen, München 2011 (in German)

22. Bundesverfassungsgericht - BVerfG, NJW 1998, 3557 (in German)

23. Simejnij kodeks Ukrayini vid 10.02.2002 №2947-III. Vidomosti Verhovnoyi Radi Ukrayini. 2002. № 21-22. st.135 (iz ostannimi zminami vid 30.03.2020) (in Ukrainian)

24. Romovska Z.V. Simejnij kodeks Ukrayini. Naukovo-praktichnij komentar [Family Code of Ukraine. Scientific and practical commentary]. Kiyiv: In Yure, 2003. $532 \mathrm{~s}$ (in Ukrainian)
25. Lorenz, A., Das Selbstbestimmungsrecht des einsichtsfähigen Minderiährigen bei Eingriffen in die körperliche Integrität, NZFam 2017, S. 782-788 (in German)

26. Stern, K., Das Staatsrecht der Bundesrepublik Deutschland, Verlag C.H. Beck 1988, Bd. III/1, § 70 V 2d (in German)

Received: $15 / 09 / 2020$ Accepted: $30 / 10 / 2020$

K. Kravchenko, lawyer of the first rank,

B. Schloer, Dr of Law (German), Associate Prof.

Taras Shevchenko National University of Kyiv, Kyiv, Ukraine

\section{MINORS AS SUBJECTS OF LAW: \\ COMPARISON OF THE LEGAL REGULATION IN GERMANY AND UKRAINE}

This article deals with the legal regulation of minors in Germany and Ukraine. Minors do not have enough intellectual ability to predict legal consequences of their acts. That is why they need a special protection. The study primarily focuses on minors as a subject of law in Civil and Family Law. The aim of the article is to study and compare legal regulation for minors under both German and Ukrainian law.

First of all, the notion of minors is analysed. It is assumed that the term minor is not clear. It has different meanings in both German and Ukrainian national law. International legislation does not clear the issue.

Second, the legal regulation of minors is studied. The issue of age limits in the national Civil Law of Germany as well as Ukraine are examined and compared. It is suggested that the age limits are closely connected to the legal capacity of the natural persons. The comparative analysis of legal regulation of minors in Civil Law of both countries shows that the provisions of German Civil Law concerning the legal capacity of minors differ sufficiently from Ukrainian ones. For example, in Germany children under seven years old do not have legal capacity, while minors at the age from seven to eighteen years old have limited legal capacity. Whereas in Ukraine, minors under fourteen years old have partial legal capacity, while minors between fourteen and eighteen years old have incomplete legal capacity.

Last but not least, the minors' rights and their scope from the point of view of a family and the state are explored. The comparison shows that the legal regulation of minors' rights as well as an attitude to the minors in society in Germany differs from Ukraine. Finally, it is proposed to ameno the Family Code of Ukraine in respect of minors' rights. It is wise to consider an opinion of minors in family issues.

Keywords: minors, rights of minors, legal capacity of minors, age limit in civil law.

Bulletin of Taras Shevchenko National University of Kyiv. Legal Studies, 2020; 3 (114): 30-35

УДК: 342.7:341.231.14

DOI: https:doi.org/10.17721/1728-2195/2020/5.115-7
ISSN 1728-2195

(C) Taras Shevchenko National University of Kyiv, Publishing center "Kyiv University", 2020

А. Крижевський, канд. іст. наук, асист. ORCID ID: 0000-0002-7234-7500,

O. Крижевська, канд. юрид. наук, асист. ORCID ID: 0000-0003-4989-6322

Київський національний університет імені Тараса Шевченка, Київ, Україна

\section{ДЕРЖАВНА ПОЛІТИКА У СФЕРІ ОХОРОНИ ЗДОРОВ'Я У ПРОВІДНИХ КРАЇНАХ ЄВРОПИ: ПРАВОВИЙ АСПЕКТ}

Досліджено державну політику у сфері охорони здоров'я у провідних країнах Європи: Швеції, ФРН і Франції. Метою цієї статті є аналіз і систематизація основних організаційно-правових засад державної політики у сфері охорони здоров'я у країнах ЄС і розроблення рекомендацій щодо вдосконалення та реформування української системи охорони здоров'я. Дослідження здійснювали з погляду принципів історизму, об'єктивності, різнобічності, взаємодоповнюваності й обгрунтованості, що створило надійну методологічну основу для комплексного аналізу предмета дослідження. У роботі застосовували порівняльно-правовий метод, формально-юридичний, системно-структурний, метод класифікації, метод моделювання, конкретно-статистичний, історико-правовий та інші методи наукового аналізу відповідно до предмета дослідження. У статmі стверджується, що державна політика у сфері охорони здоров'я унікальна в кожній країні, а на ї̈ формування вплинули історичне минуле, політичний режим, національний менталітет та інші фактори. Зазначено необхідність створення в Україні в ході реформи системи охорони здоров'я спеціального Кодексу законів у цій галузі, який сприятиме якісному правовому регулюванню відносин між пацієнтами, закладами охорони здоров'я, страховими компаніями та державою. Автори вважають, що одним із подальших напрямів реформування системи охорони здоров'я України перш за все має стати запровадження обов'язкового державного медичного страхування. Обгрунтовано, що страхування повинно здійснюватися на тристоронній основі: відрахування від доходів підприємиів, відрахування з державного бюджету та страхові внески населення. Доведено необхідність посилення заходів, спрямованих на попередження та профілактику виникнення захворюваності.

Ключові слова: охорона здоров'я, державна політика, нормативно-правове забезпечення, медичне страхування, іноземний досвід, реформа, кодекс, страхові внески.

ВСтУП. Конституцією України кожному громадянину гарантовано право на безкоштовну охорону його здоров'я, на одержання медичної допомоги і медичного страхування. Тому для будь-якої держави стабільність системи охорони здоров'я та її ефективність $€$ одним із головних завдань. Державна політика в сфері охорони здоров'я полягає у забезпеченні діяльності та розвитку системи охорони здоров'я шляхом видачі необхідних нормативно-правових актів, фоормуванні пріоритетів, доктрин, концепцій і сприянні реалізації програм, спрямованих на зміцнення здоров'я населення. Вивчення досвіду формування та функціонування державної політики в ссрері охорони здоров'я у європейських країнах у межах пошуку шляхів удосконалення та реформування української політики в цій галузі визначає актуальність цього дослідження.

Історіографрія, дотична до об'єкта, предмета, хронології та географії цієї статті, має ряд здобутків і прогалин. Серед великої кількості робіт щодо поставленої проблеми можна виділити загальні дослідження В. Воробйова [1], В. Долота [2], Ю. Матвієнка [4; 5], М. Співак [9] та інших, які присвячені проблемам систем 